\title{
ORIGINAL
}

\section{Analysis of Reaction Rate in Propoxylation}

\author{
Yoshikazu GoTOH and Takao ANDOH** \\ * AOA Research Dept. Research Division, Sanyo Chemical Industries, Ltd. \\ (11-1, Ikkyo Nomoto-cho, Higashiyama-ku, Kyoto-shi, T 605) \\ ** Research Dept. Research Division Sanyo Chemical Industries, Ltd \\ (11-1, Ikkyo Nomoto-cho, Higashiyama-ku, Kyoto-shi, $\mathbf{T} 605)$
}

\begin{abstract}
Propoxylation is useful for making materials of urethane foam and surfactants in industry. The reaction rate of the addition polymerization of propylene oxide (PO) was examined to find means for enhancing productivity. The reaction rate of propoxylation became maximum when PO concentration in the reaction mass was $33.3 \mathrm{wt} \%$. This was confirmed theoretically using the reaction rate equation proposed by Ishii et al.
\end{abstract}

\section{Introduction}

Addition polymerization of $\mathrm{PO}$ with some initiator catalyzed by sodium isopropoxide was reported by Ishii et al. in 1959'1).

They suggested that the reaction rate could be expressed as follows.

$V_{\mathrm{po}}=k_{1}$ [initiator] [PO] [ catalyst] (1)

In 1963 , the effects of catalyst concentration, reaction temperature, and molar ratio of the initiator to $\mathrm{PO}$ on the reaction rate of propoxylation were investigated ${ }^{2)}$. But the effect of $\mathrm{PO}$ concentration in reaction mass was not reported. In industrial propoxylation, it is popular that the PO dosing is continuous and changeable. Therefore, it is important to control dosing speed and concentration of $\mathrm{PO}$ in the reaction mass. The author proposed an equation concerning PO concentration in the reaction mass $^{3)}$ previously. We investigated the effect of PO concentration to the reaction rate in this paper.

\section{Experimental}

\subsection{Experimental device}

Reaction Calorimeter $\mathrm{RC}-1^{3)}$ was used for this investigation. Its effective capacity and pressure durability was $1.5 \mathrm{~L}$ and 60 $\mathrm{kgf} / \mathrm{cm}^{2}$.

\subsection{Measurement}

Corresponding author : Yoshikazu GOTOH
Molecular weight $(\mathrm{Mn})$

The number-average molecular weight $(M n)$ was calculated by Eq. (2).

$$
M n=56100 \times F / V
$$

$F$ : functionality of the initiator

$V: \mathrm{OH}-$ value $^{4}$ (estimated by the method of acetylation with phthalic anhydride)

TU value

The TU (terminal unsatulation) value was measured by ${ }^{1} \mathrm{H}-\mathrm{MNR}$ method ${ }^{5)}$ using a sampled polymer without treatment. ${ }^{1} \mathrm{H}-$ NMR spectra were recorded in deuterated chloroform $\left(\mathrm{CDCl}_{3}\right)$ and the concentration of the sampled polymer was about $5 \mathrm{wt} / \mathrm{vol}$ $\%$. Typical ${ }^{1} \mathrm{H}-\mathrm{NMR}$ spectra of a polymer obtained in this experiment on a VARIAN $\mathrm{XL}-300(300 \mathrm{MHz})$ was shown in Fig. -1 .

The TU value (meq/g) was calculated by Eq. (3).

$$
\begin{aligned}
\mathrm{TU}(\mathrm{meq} / \mathrm{g})= & \frac{\left(\mathrm{I}_{2} / 2\right)+\left(\mathrm{I}_{3} / 3\right)}{\left(\mathrm{I}_{1} / 3\right)} \\
& \cdot \frac{(M n-92)}{58} \cdot \frac{1000}{M n}
\end{aligned}
$$

58 : molecular weight of $\mathrm{PO}$

92 : molecular weight of glycerol (initiator)

$M n$ :molecular weight of the sampled polymer

A signal due to methyl protons of $\mathrm{PO}$ was shifted $0.1 \sim 0.2 \mathrm{ppm}$ upper to that of poly- 


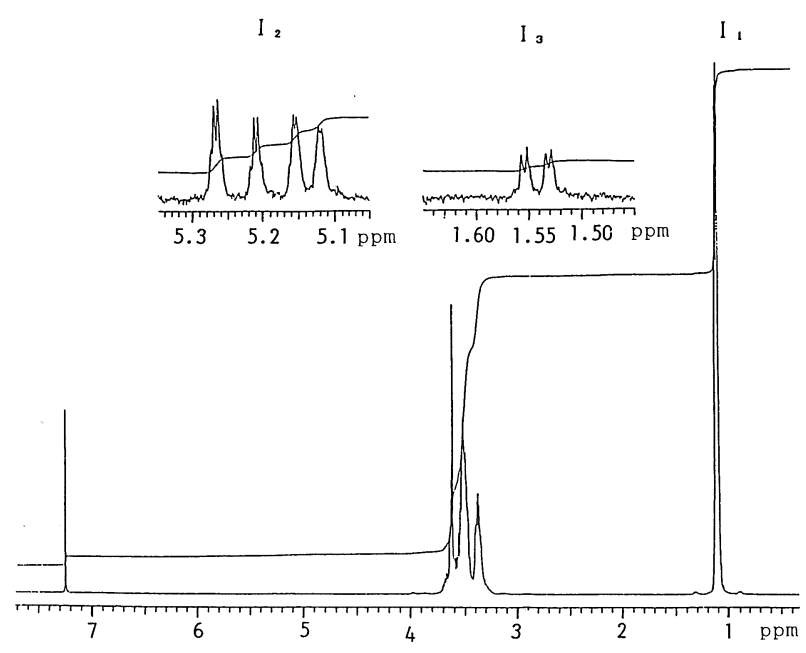

Fig.-1 Typical ${ }^{1} \mathrm{H}-\mathrm{NMR}$ spectra of a polymer.

mers, so existence of non-reacted PO was not troublesome in estimating the TU values.

$\mathrm{PO}$ concentration in reaction mass

PO concentration in reaction mass was calculated by Eq. (4) ${ }^{3)}$.

$\log C=1.3238 \log P+(1411.7 / T)-3.3148$

$C: \mathrm{PO}$ concentration (wt \%) in reaction mass

$P$ : Abs. pressure $\left(\mathrm{kgf} / \mathrm{cm}^{2}\right)$

$T$ : Abs. temperature $(\mathrm{K})$

Eq. (4) was obtained by the analysis of the pressure/PO concentration curves shown in Fig. -2 .

\subsection{Materials}

Polyether A (initiator, prepared by authors) was a glycerol/PO addition product, $M n$ of it was 628 , and concentration of catalyst (potassium hydroxide) was 1.35 wt \% (purity-accounted).

PO was a commercial grade produced by Showa Denko Co., Ltd.

Potassium hydroxide was a commercial grade produced by Asahi Glass Co., Ltd (48 $\%$ aqueous solution).

Glycerol was a commercial grade produced by Nippon Oils \& Fats Co., LTD.

\subsection{Method of Experiment}

Polyether A was charged in $\mathrm{RC}-1$, and controlled at certain level of temperature under reduced pressure with stirring. After

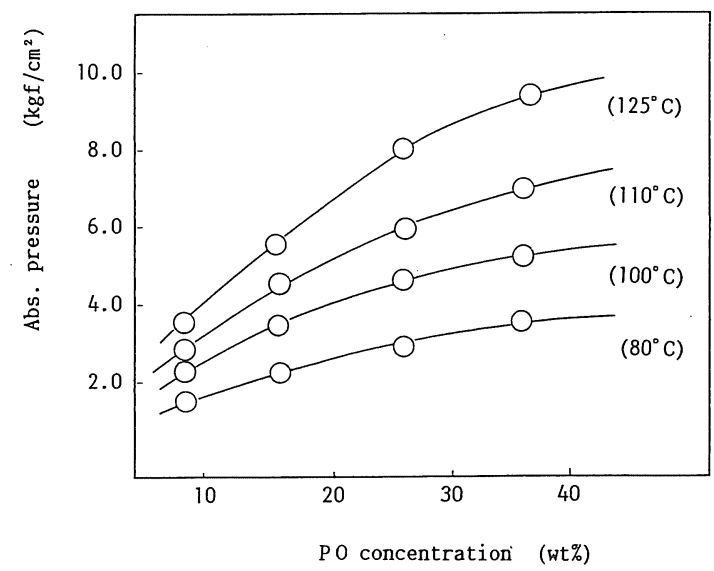

Fig.-2 The pressure/PO concentration curve at each temperature.

this treatment, dosing of PO was started under $0 \mathrm{kgf} / \mathrm{cm}^{2}$. And dosing of $\mathrm{PO}$ was continued untill the end of experiment to keep certain level of PO concentration in the reaction mass. Sampling was carried out in every $1 \mathrm{~h}$, and $M n$ of the sampled polymer was measured after stripping of PO under reduced pressure.

\subsection{Evaluation}

Reaction time required was defined as the time when $M n$ of the polymer reached to 3,000 .

\section{Results}

The explanation of dosing pattern of $\mathrm{PO}$ and reaction time required (time for poly- 
merization reached to 3,000 of $M n$ ) are shown in Fig. -3 .

TU values by analyzing samples synthesized at $120^{\circ} \mathrm{C}(\mathrm{Mn}: 3,000)$ are shown in Fig. -4. It is cleared that the TU value is independent of PO concentration. The relations between reaction time required and $\mathrm{PO}$ concentration in reaction mass are also shown in Fig. -4. Each curve has the minimum point, which is located at about $33 \mathrm{wt}$ $\%$ of PO concentration.

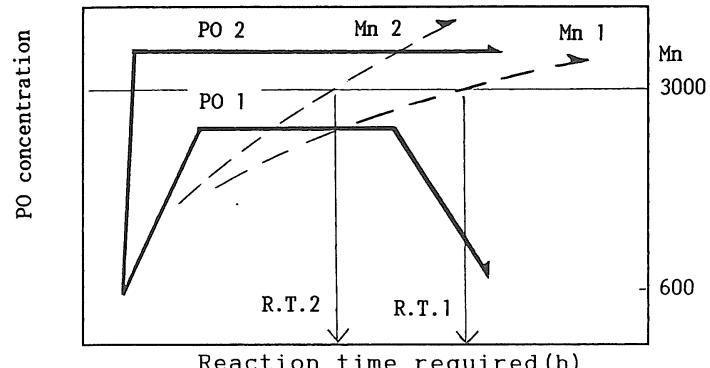

Exp. 1 Typical pattern of propoxylation in industry

Exp. 2 Special pattern experimented in this paper

PO 1,2 Dosing patterns of PO in Exp. 1,2

R.T. 1,2 Reaction time required in Exp. 1,2

Mn 1,2 Mn curve of polymer obtained in Exp. 1,2

Fig. -3 Dosing patterns of $\mathrm{PO}$ and reaction time required.
This means that reaction rate of propoxylation is maximum as $\mathrm{PO}$ concentration nears to 33 wt $\%$. And this result could be expected mathematically as follows.

Now, we assume that $A \mathrm{~kg}$ of initiator $(M n: a), B \mathrm{~kg}$ of catalyst $(\mathrm{Mn}: b)$ and $X$ $\mathrm{kg}$ of PO ( $\mathrm{Mn}: 58)$ are charged in reactor, then reaction velocity could be expressed.

$$
\begin{aligned}
V_{\mathrm{po}}= & k_{2} \cdot \frac{(X / 58)}{(A+B+X)} \cdot \frac{(A / a)}{(A+B+X)} \\
& \cdot \frac{(B / b)}{(A+B+X)}=K \cdot \frac{X}{(A+B+X)^{3}}
\end{aligned}
$$

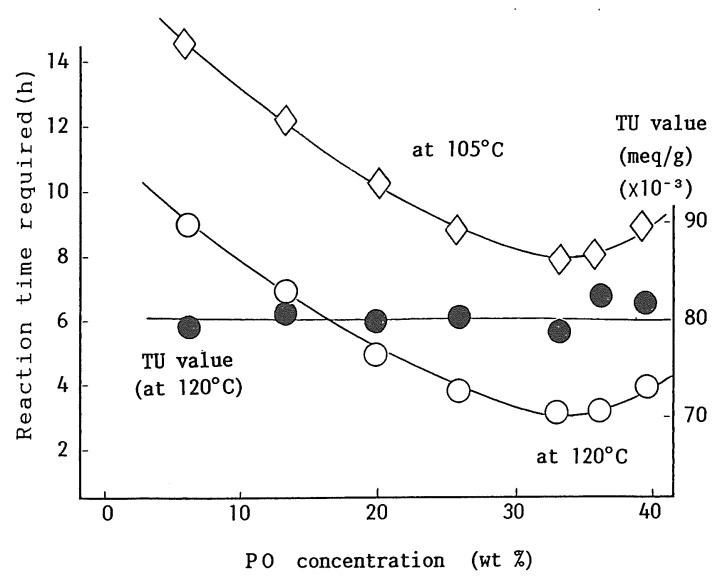

Fig. -4 Relation between PO concentration and the reaction time required and $\mathrm{TU}$ value.

\begin{tabular}{|c|c|c|c|c|c|}
\hline No. & 1 & 2 & 3 & 4 & 5 \\
\hline Polyether A (g) & 200 & 200 & 200 & 200 & 200 \\
\hline $\mathrm{PO} \quad(\mathrm{g})$ & 800 & 200 & 100 & 50 & 10.5 \\
\hline (wt \%) & 80 & 50 & 33.3 & 20 & 5 \\
\hline Ratio of $V_{\mathrm{po}^{*}}$ & 0.22 & 0.84 & 1.00 & 0.86 & 0.35 \\
\hline
\end{tabular}

Table-1 Comparison of reaction rate at each PO concentration.

* Standard : $V_{\text {po }}$ value of No. 3

Table-2 Maximum pressure and temperature in runaway propoxylation ${ }^{6}$. (Phosphoric acid as chemical stopper)

\begin{tabular}{l|c|c|c|c}
\hline \multicolumn{1}{c|}{ Chemical stopper } & \multicolumn{2}{c|}{ Without dosing } & \multicolumn{2}{c}{ With dosing } \\
\hline Condition* & $105^{\circ} \mathrm{C} \times 28$ wt $\%$ & $120^{\circ} \mathrm{C} \times 28$ wt $\%$ & $105^{\circ} \mathrm{C} \times 28$ wt $\%$ & $120^{\circ} \mathrm{C} \times 28 \mathrm{wt} \%$ \\
\hline Abs. press. $\left(\mathrm{kgf} / \mathrm{cm}^{2}\right)$ & 10.8 & 14.2 & 7.4 & 11.7 \\
\hline Temperature $\left({ }^{\circ} \mathrm{C}\right)$ & $267^{*}$ & $281^{*}$ & 126 & 154 \\
\hline
\end{tabular}

Condition* : temperature and $\mathrm{PO}$ conc. in reaction mass at starting time of runaway propoxylation

Temperature* : evaluated by $\mathrm{RC}-1$ at $\mathrm{Tr}$ mode ${ }^{6}$ ) 
Replacement with new constants, $K=k_{2}$ • $(1 / 58) \cdot(A / a) \cdot(B / b)$ and $C=A+B$, yields

$$
V_{\mathrm{po}}=K \cdot \frac{X}{(C+X)^{3}}
$$

$V_{\text {po }}$ is maximum when $\mathrm{d} V_{\mathrm{po}} / \mathrm{d} X=0$. The following shows a detail of the calculation.

$$
\begin{aligned}
& \frac{\mathrm{d} V_{\mathrm{po}}}{\mathrm{d} X}=K \cdot \frac{(C+X)^{3}-3 X(C+X)^{2}}{(C+X)^{6}} \\
& =K \cdot \frac{C-2 X}{(C+X)^{4}} \\
& \mathrm{~d} V_{\mathrm{po}} / \mathrm{d} X=0 \rightarrow X=\mathrm{C} / 2
\end{aligned}
$$

This means that maximum reaction rate is obtained when $\mathrm{PO}$ concentration in reaction mass is $33.3 \mathrm{wt} \%$ (a half quantity of initiator and catalyst). The $V_{\text {po values cal- }}$ culated from equation (5) are shown in Table-1.

\section{Discussion}

Reaction rate can be accelerated by increase in reaction temperature or concentration of catalyst. In the former case, the $\mathrm{TU}$ value increases exponentially, and in the latter, the TU value increases a little by increase in catalyst concentration ${ }^{2}$. Acceleration of reaction rate by the control of $\mathrm{PO}$ concentration (up to maximum, 33.3 wt \%) needs no investment and increases little TU value. Since it has been confirmed ${ }^{6)}$ to be safe even when reaction runs away, to control PO concentration seems to be the best way to increase productivity.

(Received Sept. 30, 1992)

\section{References}

1) Y. Ishii, J. Sekiguchi, and S. Itoh, $K O$ HGYOH KAGAKU ZASSHI, 62, 86 (1959).

2) H. Tokunoh, H. Kathunuma, and K. Nikaidoh, Yukagaku, 12, 159 (1963).

3) Y. Gotoh, J. Jpn. Oil Chem. Soc. (YUKAGAKU), 41, 489 (1992).

4) JIS K 1557-1970

5) Y. Gotoh, KOBUNSHI RONBUNSHU, 50, 121 (1993).

6) Y. Gotoh and T. Andoh, J. Jpn. Oil Chem. Soc. (YUKAGAKU), 42, 17 (1993).

\section{プロポキシレーションの反応速度解析}

\section{五藤芳和 ${ }^{*}$ ・安藤孝夫 ${ }^{* *}$}

* 三洋化成工業株式会社研究本部 AOA 研究部

( ( 605 京都市東山区一橋野本町 11-1)

** 三洋化成工業株式会社研究本部技術開拓研究室

（于 605 京都市東山区一橋野本町 11-1)

プロポキシレーションはウレタンフォーム用の原料, 界面活性剤などの工業的な製造手段として有用である。 われわれは生産性の向上を図ることを目的にプロピレ ンオキシド (以下, PO と略す) の逐次付加重合反応に おける反応速度の解析を実施した。

その結果, $\mathrm{PO}$ を連続的に投入する重合方法において は, 反応液相中の $\mathrm{PO}$ 濃度を $33.3 \mathrm{wt} \%$ に保つとき最 高の反応速度が得られることを実験によって実証し，か つ石井らの提唱した反応速度式から理論的に予測し得る ことを明らかにした。

連絡者 五藤芳和 